\title{
Analysis of Scientifically Gifted Students' Affective Characterization in Rural Area
}

\author{
Chunryol Ryu ${ }^{1}$, Jiyoung Ryu ${ }^{2}$ and Jiseon $\mathrm{Kim}^{3}$ \\ 1,2,3 Gifted Institute for Talented Education, KAIST \\ 1 pioong@kaist.ac.kr, ${ }^{2}$ jryu01@kaist.ac.kr, ${ }^{3}$ jskim315@kaist.ac.kr
}

\begin{abstract}
The purpose of this research is on investigating the relationship between affective domain and academic achievement of gifted students form rural area, and furthermore through this investigation, analyzing the study habits of these students. For the research, 105 science gifted students from rural area and 131 general science gifted students who were provided with cyber-class education. Throughout the class, conviction, accomplishment motivation, task commitment, and achievement of learning about emotional intelligence, self-regulated learning ability, and intellectual capacity were analyzed. As a result, students from the rural area showed a similar correlation between academic achievement and active problem-solving driven by motive control and internal motive. Also, rural area students showed the tendency of lower self-regulated learning ability and achievement motivation compare to general gifted students, and furthermore were analyzed as having lower behavior control (one of the selfregulated learning abilities) When an educational program for rural area students is designed, measures for enhancing self-regulated learning ability and inner motivation should be considered.
\end{abstract}

Keywords: Rural area, Science gifted students, Emotional intelligence, Self-regulated Learning, Intellectual ability, Achievement motivation

\section{Introduction}

Conventional definition of rural area is the area that's contrary to a developing area or a city. It's commonly thought as agricultural, mountain, fishing villages, islands, areas with economic depression, or under developing area. Today, definition of rural area is a relative notion. In the past, it was the area of poverty but today, It not only covers economical aspect but also very broad aspects such as social, administrative, cultural, educational, and environmental side [12]. As a typical rural area, there are farming and fishing villages. These villages lack infrastructure and cultural facilities for education, resulting comparatively poorer educational environment than cities. For this reason, many students from these villages move to cities and this change makes students staying in the villages have a feeling of loss. This is the major reason causing students left in the villages to face decline of motivation to study and self-esteem. Self-esteem has a correlation with academic achievement, school life satisfaction, and internal-external control to adolescent. Especially self-esteem is in a close relationship with adolescents choosing their occupation in the future and career maturity [4].

Article history:

Received (September 16, 2016), Review Result (November 20, 2016), Accepted (December 01, 2016) 
The object in this research is to investigate factors affecting characteristics and achievements of science gifted students from rural area, and analyzing their learning characteristics.

Detailed research problems raised for the research are as follows.

First, what is the factor affecting the achievements of science gifted students form the rural area?

Second, what kind of difference do rural area students and urban area students have in affective domain?

\section{Literature review}

\subsection{Science gifted students from rural area}

The domain of gifted student from neglected class contains student from socially, economically neglected family, multi-cultural family, area that's geographically isolated from advance education, North Korea and students with disability [12]. In other words, it's a student who's from the class which cannot get a chance of getting advance education.

One can classify neglected class as follows according to limited chance of education.

1) Students from socially, economically neglected family

2) Students from multi-cultural family

3) Students from area that's geographically isolated from advance education

4) Students with disability, students from North Korea, and students with the lack of benefit in certain areas.

That is, 'One who even though doesn't have overall superior school record and only shows outstanding outcome in science, but do not have any experience on educational service other than school because of financial problem and geographical position.' is the definition.

\subsection{Development of giftedness of science gifted students in rural area}

Renzulli (1978) consider giftedness to be composed of "above average ability," "task commitment", and "creativity". He claims that "task commitment" and "creativity" are developmental concept which gets a great amount of effect from environment of experiences during growth process [10]. In three notions of Renzulli, both developmental and stationary concepts are contained. Ability is a stationary concept that gets fixed by heredity and environment of baby life. After on, ability doesn't change considerably by the environment. In contrast, task commitment and creativity can be more developed or decay throughout the environment of experience during growth process. If this concept is applied to neglected gifted students, only the ability should be the criteria for distinguishing. Since creative and task commitment gets affected greatly by the environment, it's desirable to select students through their abilities which gets affected little by negative environment. It is necessary to provide abundant and high quality educational environment for students selected through ability criteria to enhance task commitment and creativity.

Gagné (2003) distinguishes giftedness and talent through "Differentiated Model of Gifted and Talent, DMGT" [2]. According to his opinion, giftedness is spontaneously 
expressed potential or inborn ability (or aptitude), and should have at least one ability in that ability field that's in top $10 \%$ of students at that age. Talent, on the other hand, is systematically developed ability (or technique) or knowledge in human's field of activity, and it also should have at least one ability in that ability field that's in top $10 \%$ of students at that age. About the relationship between giftedness and talent, Gagné (2003) mentions that through systematically educating and practicing, whether it's formal or informal, inborn giftedness (or aptitude) can be gradually shown in human field of activity and achievements. This transferring of giftedness to show in human field of activity is so-called talent [2]. In a process of developing giftedness into special talent like above, the effect of "intrapersonal catalysts," "environmental catalysts" and opportunity are all proposed.

According to these assertions, rural area students have a stronger psychological sense of distance than urban area students, and the hypothesis that difference in task commitment and creativity domain affected by learning exists can be made. Namely, giftedness can be well developed or not depending on the environment. In this aspect, even though rural area students are born with superb potential, there's a high possibility of not being able to develop their potentials due to insufficient opportunity of education. Recently, there has been researches to comprehend characteristics of gifted students from various fields including recognition psychology and behavioral psychology.

Renzulli et al., (2002) proposed behavior characteristic such as learning, creativity, motivation, leadership, mathematical, scientific characteristic that can be shown in gifted students in various fields [9]. Mayer and Salovey (1997) proposed emotional intelligence model specified into recognition and expression of emotion, promotion of thinking, application, and regulation [5]. Also, based on points that gifted students know very well about their own abilities [5] and motivation is an important variable in developing giftedness [6]s, researches analyzing characteristics of gifted students on various fields such as conviction, accomplishment motivation, and etc. on self-regulated learning ability and intellectual capacity were made [5]. According to researches mentioned above, one can predict that rural area students will show a difference in various behavior domain including creativity and task commitment compare to urban area students.

\section{Research method}

For this research, $1057^{\text {th }}$ grade students that belong to rural area (farming and fishing villages) with potential of giftedness were selected and compared with 131 students who are taking gifted and talented education program in K-university in Daejeon. Both groups participated in cyber gifted and talented education program, and their learning participation throughout the study course was observed. The observation result were digitize into task commitment and learning accomplishment, and used for analysis. To select students for the research, "SRBCSS; Scales for Rating the Behavioral Characteristics of Superior Students" was used. SRBCSS, made by Renzulli et al. (2002), is a checklist for checking characteristics of gifted students. It's also used to figure out for selecting students for gifted and talented education service or grasping the emotion of students [10].

To analyze affective domain such as conviction, achievement motivation [7], progressive matrix recognition ability [8] about emotion intelligence[5], self-regulated learning ability [13], and intellectual capacity [1], various surveys were done. SPSS 12.0 was used to compute frequency and average of data (gifted and talented education state for rural area students and gifted students' characteristics) For comparing differences depending on 
variables (gender, grade, and etc.) of gifted students, cross analysis, independent sample t-test and one-way ANOVA were done.

\section{Result}

The analysis on the relationship between affective domain of neglected science gifted students and academic achievement was done. The affective characteristic was digitized through conviction and achievement motivation about self-regulated learning ability and intellectual capacity. The achievement level was digitized through task commitment and academic achievement level. As result of analysis, just like [Table 1], students' achievement had a correlation $(r=0.303, p<.01)$ with intelligence (Raven's progressive matrix recognition ability) Motivation control, one of the self-regulated learning abilities, also had a correlation $(r=0.258, p<.05)$ with students' achievement. Furthermore, students' achievement showed a correlation $(r=0.503, p<.01)$ with active problem solving due to internal motivation, one of the achievement motivation.

Table 1. Relationship between neglected students' affective character level and academic achievement

\begin{tabular}{|c|c|c|c|c|}
\hline \multirow{2}{*}{ Classification } & Factor & $\mathrm{N}$ & $\begin{array}{c}\text { Pearson } \\
\text { correlation } \\
\text { coefficient }(r)\end{array}$ & Sig \\
\hline Intelligence & progressive matrix recognition ability & 92 & $.303^{* *}$ & .003 \\
\hline \multirow{2}{*}{$\begin{array}{c}\text { Self-regulated } \\
\text { learning ability }\end{array}$} & Cognitive regulation & 77 & .088 & .470 \\
\cline { 2 - 5 } & Motivational regulation & 77 & .258 & .031 \\
\hline $\begin{array}{c}\text { Conviction on } \\
\text { intellectual } \\
\text { capacity }\end{array}$ & Behavior regulation & 77 & .028 & .817 \\
\cline { 2 - 5 } & $\begin{array}{c}\text { Understanding of possibility of intelligence } \\
\text { improvement }\end{array}$ & 47 & -.135 & .366 \\
\hline \multirow{2}{*}{$\begin{array}{c}\text { Achievement } \\
\text { motivation }\end{array}$} & $\begin{array}{c}\text { Active problem solving due to internal } \\
\text { motivation }\end{array}$ & 47 & .048 & .750 \\
\cline { 2 - 5 } & Tendency to avoid & 47 & $.503 * *$ & .000 \\
\cline { 2 - 5 } & Pursuit of social stability & 47 & .141 & .344 \\
\hline
\end{tabular}

Comparing rural area and urban area like [Table 2] below, students from urban area had higher average of cognitive regulation, motivational regulation, and behavior regulation than students from rural area. However, only in behavior regulation, the statistically meaningful difference were shown. The rural area students showed lower behavior regulation $(t=3.629$, $p<.01)$

Table 2. Comparison of self-regulated learning ability between rural and urban area students

\begin{tabular}{|c|c|c|c|c|c|}
\hline Classification & Rural area(N=48) & Urban area(N=79) & Mean difference & $t$ & Sig \\
\hline $\begin{array}{c}\text { Cognitive } \\
\text { regulation }\end{array}$ & 3.91 & 4.03 & -0.12 & -1.246 & .215 \\
\hline $\begin{array}{c}\text { Motivational } \\
\text { regulation }\end{array}$ & 4.18 & 4.34 & -0.15 & -1.668 & .098 \\
\hline $\begin{array}{c}\text { Behavior } \\
\text { regulation }\end{array}$ & 3.59 & 3.94 & -0.35 & $-3.629^{* *}$ & .000 \\
\hline
\end{tabular}

The data of comparison between rural area and urban area gifted students' conviction on intellectual capacity are shown in [Table 3] below. According to [Table 3], statistically meaningful difference could not be found. 
Table 3. Comparison between rural area and urban area gifted students' conviction on intellectual capacity

\begin{tabular}{|c|c|c|c|c|c|}
\hline Classification & Rural area(N=48) & Urban area(N=79) & Mean difference & $t$ & Sig \\
\hline $\begin{array}{c}\text { Understanding of } \\
\text { possibility of } \\
\text { intelligence } \\
\text { improvement }\end{array}$ & 1.98 & 1.92 & 0.06 & .352 & .725 \\
\hline $\begin{array}{c}\text { Understanding of } \\
\text { own intellectual } \\
\text { intelligence }\end{array}$ & 2.98 & 3.02 & -0.04 & -.683 & .496 \\
\hline
\end{tabular}

The data of comparison between rural area and urban area students' accomplishment motivation are shown in [Table 4]. Lower value means more importance. According to the table, rural area students showed higher pursuit of social stability $(t=2.124, p<.05)$

Table 4. Comparison between rural area and urban area students' accomplishment motivation

\begin{tabular}{|c|c|c|c|c|c|}
\hline Classification & Rural area(N=48) & Urban area(N=79) & Mean difference & $t$ & Sig \\
\hline $\begin{array}{c}\text { Active problem } \\
\text { solving due to } \\
\text { internal motive }\end{array}$ & 1.12 & 1.11 & 0.01 & .426 & .671 \\
\hline Tendency to avoid & 1.70 & 1.77 & -0.07 & -1.541 & .126 \\
\hline $\begin{array}{c}\text { pursuit of social } \\
\text { stability }\end{array}$ & 1.09 & 1.18 & -0.08 & $-2.124^{*}$ & .036 \\
\hline
\end{tabular}

\section{Conclusion and discussion}

Many researches on rural area assert that continuously leaving people and geographical isolation from educational services are the main reasons for different affective domain between rural area and urban area students. According to this assertion, there's a low chance for gifted students in rural area to develop their potentials due to lack of educational chance. This research was based on the awareness of a problem above. Examination on differences between affective character of area and urban area gifted students, and investigation on the factors that affect the achievement of rural area students were done. For this research, 105 students from rural area and 131 students from urban area were selected and putted under 4 months of cyber gifted and talented education program. Throughout the program, recognition and affective character were measured through conviction, achievement motivation, progressive matrix recognition ability about emotion intelligence, self-regulated learning ability, and intellectual capacity. The result of analysis showed that area and urban area students had some meaningful difference in recognition and affective sides such as selfregulated learning ability and achievement motivation. Also, self-regulated learning ability and achievement motive turned out to be in related with alienated students' achievement. More specific analysis is as follows.

First, achievement of rural area students have a correlation with intelligence, motivation regulation of self-regulated learning, and active problem solving due to internal motivation.

Second, there is a meaningful difference of behavior regulation of self-regulated learning and external motivation of achievement motivation between area and urban area students. Self-regulated learning ability is an important factor that controls the complex interaction among recognition, motivation, and behaviour factors [7].

This research also shows that affective character affects achievement of rural area students, and there is a difference in affective character between rural area and urban area. Based on 
these results, measures to enhance self-regulated learning ability and internal motivation should be considered when education program for alienated gifted students is in development. Especially, to develop behavior regulation ability that controls concrete learning, measures that consider affective domain and diverse activities that enhance internal motivation should be considered.

\section{References}

[1] C. S. Dweck, "Motivational processes affect learning," American Psychologist, vol.41, pp.1040-1048

[2] F. Gagné, "Transforming gifts into talents: The DMGT as a developmental theory," In N. Colangelo \& G. A. Davis (Eds.), Handbook of gifted education (3rd) (pp.60-74), Boston: Pearson Education, Inc., (2003)

[3] A.E. Gottfried, and A.W. Gottfried, "A Longitudinal study of academic intrinsic motivation in intellectually gifted children: Childhood through early adolescence," Gifted Child Quarterly, vol.40, no.4, pp.179-183, (2003)

[4] O. S. Kim, "The relationship among the types of parent-adolescents communication," Self-Esteem and Career Maturity of High School Students, Master's Thesis, Sogang University, (2001)

[5] J.D. Mayer and P. Salovey, "What is emotional intelligence?" In P. Salovey \& D. Sluyter (Eds.), "Emotional development and emotional intelligence: Implications for educators," New York: Basic Books, pp.3-31

[6] M.G. Moore, "Learner autonomy: the second dimension of independent learning," Convergence, vol.5, no.2, pp.76-88

[7] J.G. Nicholls, "Achievement motivation: Conceptions of ability, subjective experience, task choice, and performance,” Psychological Review, vol.91, pp.328-346

[8] J. Raven, J.C. Raven, and J.H. Court, "Manual for raven's progressive matrices and vocabulary scales," San Antonio, TX: Harcourt Assessment, (2003)

[9] J.R. Renzulli, L.H. Smith, A.J. White, C.M. Callahan, and R.K. Hartman, "Scale for rating," Behavioral Characteristics of Superior Students, ERIC, (2002)

[10] J.S. Renzulli, "What makes giftedness? Re-examining a definition,” Phi Delta Kappan, vol.60, no.3, pp.180184 and 261

[11] H. Wagner, N. Neber, and K.A. Heller, "The Bundes Schüler Akademie: A residential summer program for gifted adolescents in Germany," In M. W. Katzko \& F. J. Mönks (Eds.), "Nurturing talent. Individual needs and social ability," Proceedings of the Fourth Conference of the European Council for High Ability, Assen, The Netherlands: Van Gorcum, pp.281-291

[12] H.R. Woo, “A study on the public art for culture welfare in alienation area," Master's Thesis, Hongik University, (2008)

[13] M.H. Yang, "The study on the development and validation of self-regulated learning model," Doctoral dissertation, Seoul National University, (2000)

[14] A. Ziegler and K. Heller, "Conceptions of giftedness from a Meta-theoretical Perspective," In K. Heller, F. Monks, R. Sternberg, \& R. Subotnik (Eds.), International Handbook of Giftedness and Talent, New York: Elsevier Science, pp.3-21, (2000) 